\title{
Malabsorption and nutritional balance in the ICU: fecal weight as a biomarker: a prospective observational pilot study
}

\author{
Nicolette J Wierdsma ${ }^{1 *}$, Job HC Peters ${ }^{2}$, Peter JM Weijs ${ }^{1}$, Martjin B Keur ${ }^{3}$, Armand RJ Girbes ${ }^{3}$, \\ Ad A van Bodegraven ${ }^{4}$ and Albertus Beishuizen ${ }^{3}$
}

\begin{abstract}
Introduction: Malabsorption, which is frequently underdiagnosed in critically ill patients, is clinically relevant with regard to nutritional balance and nutritional management. We aimed to validate the diagnostic accuracy of fecal weight as a biomarker for fecal loss and additionally to assess fecal macronutrient contents and intestinal absorption capacity in ICU patients.

Methods: This was an observational pilot study in a tertiary mixed medical-surgical ICU in hemodynamically stable adult ICU patients, without clinically evident gastrointestinal malfunction. Fecal weight (grams/day), fecal energy (by bomb calorimetry in kcal/day), and macronutrient content (fat, protein, and carbohydrate in grams/day) were measured. Diagnostic accuracy expressed in terms of test sensitivity, specificity, positive (PPV) and negative predictive value (NPV), and receiver operator curves (ROCs) were calculated for fecal weight as a marker for energy malabsorption. Malabsorption was a priori defined as $<85 \%$ intestinal absorption capacity.

Results: Forty-eight patients (63 \pm 15 years; 58\% men) receiving full enteral feeding were included. A cut-off fecal production of $>350 \mathrm{~g} /$ day (that is, diarrhea) was linked to the optimal ROC (0.879), showing a sensitivity and PPV of $80 \%$, respectively. Specificity and NPV were both $96 \%$. Fecal weight (grams/day) and intestinal energy-absorption capacity were inversely correlated $(r=-0.69 ; P<0.001)$. Patients with $>350 \mathrm{~g}$ feces/day had a significantly morenegative energy balance compared with patients with $<350 \mathrm{~g}$ feces/day (loss of $627 \mathrm{kcal} /$ day versus neutral balance; $P=0.012$ ).

Conclusions: A fecal weight $>350 \mathrm{~g} /$ day in ICU patients is a biomarker applicable in daily practice, which can act as a surrogate for fecal energy loss and intestinal energy absorption. Daily measurement of fecal weight is a feasible means of monitoring the nutritional status of critically ill patients and, in those identified as having malabsorption, can monitor responses to changes in dietary management.
\end{abstract}

\section{Introduction}

A persistent negative energy balance, known as proteinenergy malnutrition (PEM), depletes lean tissue and adipose mass. In critically ill patients, PEM is strongly correlated with complications, especially infections [1]. In general, malnutrition in critically ill patients is associated with impaired immune function, an increased risk of infections, and an increased mortality rate [2-5]. The

\footnotetext{
* Correspondence: N.Wierdsma@vumc.nl

'Department of Nutrition and Dietetics, VU University Medical Center, De Boelelaan 1117, 1081 HV Amsterdam, The Netherlands

Full list of author information is available at the end of the article
}

latter is linearly related to severity of gastrointestinal failure, as determined by the gastrointestinal failure score (GIF) in ICU patients, which reflects mainly the feasibility of adequate enteral feeding [6].

Patients admitted to an ICU are frequently malnourished and catabolic [7], and therefore, nutrition with adequate amounts of energy and protein, preferably as early as clinically possible via the enteral route, has been strongly recommended [8-11]. It has been demonstrated that it might be difficult to supply the prescribed amount of enteral nutrition in ICU patients, such as in patients with severe hemodynamic failure [12]. Optimal
C Biomed Central

(c) 2011 Weirdsma et al.; licensee BioMed Central Ltd. This is an open access article distributed under the terms of the Creative Commons Attribution License (http://creativecommons.org/licenses/by/2.0), which permits unrestricted use, distribution, and reproduction in any medium, provided the original work is properly cited. 
enteral nutrition aims to reduce stress-related metabolic catabolism, to decrease the likelihood of bacterial translocation, and to maintain intestinal mucosal integrity [13]. Because nutritional support does not often meet energy requirements of ICU patients, energy will be derived from body reserves, contributing to the already existing catabolic state $[14,15]$; adequate and individually customized feeding is believed to be an essential part of treatment of these patients. Both sufficient energy and sufficient protein provision are crucial to ensuring optimal nutrition of this population. Based on current literature, optimal energy needs can be calculated from measured resting energy expenditure (REE) $+10 \%$ $[16,17]$. It has been suggested that the optimal protein supply is 1.2 to $1.5 \mathrm{~g} / \mathrm{kg}$ pre-illness body weight/day for ICU patients [8,18-20].

Gastrointestinal dysfunction occurs frequently in critically ill patients and is associated with adverse outcomes [21-25]. Because malabsorption may induce and worsen PEM, not only are determining nutritional needs and providing adequate nutritional intake essential, but in addition, nutrient losses have to be considered [26]. Diarrhea, which can be an indicator of malabsorption, is a common feature of ICU patients with multiple organ failure (MOF) and is often neglected in daily ICU practice, resulting in potentially important energy and nutrient losses.

In a former study, we demonstrated that malabsorption is a commonly occurring and neglected clinical problem, contributing to a negative energy balance in one of three ICU patients with diarrhea, and from these data, a fecal weight of $>250 \mathrm{~g} /$ day was proposed as a biomarker of malabsorption [27]. This previous small series was extended in the present study to validate fecal weight as a biomarker and to characterize in detail the extent and type of fecal nutrient losses in ICU patients.

Therefore, the aim of the present study is first, to validate the diagnostic accuracy of fecal weight as a marker for fecal energy malabsorption. Second, we aimed to assess fecal macronutrient contents, and subsequently to calculate intestinal absorption capacity of energy and macronutrients in hemodynamically and respiratorily stable ICU patients without known gastrointestinal dysfunction.

\section{Materials and methods Design}

This prospective observational pilot study was conducted in a tertiary, mixed medical-surgical academic ICU and focuses on intestinal digestive function. The methods used aimed to measure fecal energy and nutrient losses and subsequently to calculate intestinal absorption capacity from the data obtained. The study extended a previously reported cohort [27].

\section{Patients}

ICU patients had to meet the following criteria for inclusion (a) fully fed with an enteral tube during the previous 2 days, (b) stable hemodynamics and respiratory function according to the treating intensivists, (c) mechanical ventilation with $\mathrm{PaO}_{2} / \mathrm{FiO}_{2}$ ratio $>200$ and positive end-expiratory pressure $(\mathrm{PEEP})<15 \mathrm{~cm} \mathrm{H}_{2} \mathrm{O}$, (d) expected length of stay in the ICU three or more days with continuation of enteral nutrition alone, and (e) a stable preadmission weight and no apparent nutritional deficiencies before admission to the ICU. Patients with liver failure, renal failure requiring CRRT (continuous renal replacement therapy), total parenteral nutrition (TPN), and patients with a known intestinal disease or failure (such as stomata, inflammatory bowel disease (IBD), chronic intermittent intestinal pseudooobstruction (CIIP), gastrointestinal tumor, celiac disease, shortbowel syndrome, and so on) were excluded.

Forty-eight consecutive patients were included, and full stool-composition analysis was performed (weight, and amount of energy, fat, protein, and carbohydrates) in 35 patients. In the remaining 13 patients, only fecal weight, energy, and fat content could be assessed (hence, missing values of fecal protein and subsequently calculated carbohydrate content for technical laboratory reasons in the beginning of the study period).

Based on data of the receiver operator curves (ROCs) of stool volume, we divided the patients into two groups (that is, a group with apparent and so-called normal stools (considered not to have malabsorption), and a diarrhea group (with malabsorption).

The Medical Ethics Committee of the VU University Medical Center, Amsterdam, The Netherlands, approved the study protocol, and informed consent by proxy (relatives or contacts) was obtained from the patients.

\section{Methods}

Routinely collected patient data such as APACHE-II score, SOFA score (Sequential Organ Failure Assessment), anthropometric, demographic, and medical data were extracted from the patient data-management system (PDMS; Metavision, Tel Aviv, Israel). Patients' energetic needs were determined by measuring resting energy expenditure (REE) for a minimum of 1.5 hours by indirect calorimetry at baseline [28], by using Datex Deltatrac MBM 100 metabolic monitor (DatexEngstrom Division, Instrumentation Corp., Helsinki, Finland) after calibration with calibration gas containing $95 \% \mathrm{O}_{2}$ and $5 \% \mathrm{CO}_{2}$ before each measurement. The total energy expenditure (TEE) was calculated by adding $10 \%$ activity energy expenditure (AEE) to the REE, as recommended in ventilated ICU patients [29].

The actual nutritional intake of energy (TEN), fat, proteins, and carbohydrates was calculated from daily 
digitalized registration of supplied amounts of enteral nutrition by using gross energetic values (carbohydrate, $4.10 \mathrm{kcal} / \mathrm{g}$; fat, $9.40 \mathrm{kcal} / \mathrm{g}$; and protein, $5.65 \mathrm{kcal} / \mathrm{g}$ ). These values were adjusted or corrected for urinary nitrogen loss of $1.25 \mathrm{kcal} / \mathrm{g}$, thus reaching a value of 4.4 $\mathrm{kcal} / \mathrm{g}[30,31]$ per milliliter of feeding. The total amount provided to the patient could thus be calculated by multiplying this by the volume of enteral feeding provided. The no-residue enteral nutrition (Nutrison Standaard/ Nutrison Protein Plus/Nutrison Concentrated; Nutricia, Zoetermeer, The Netherlands; or Promote; Abbott Laboratories, Hoofddorp, The Netherlands) was continued during measurements, adjusted according to TEE findings by using our computerized energy/protein algorithm [32], and it subsequently remained unchanged during the study period. This exact amount of delivered feeding was monitored in the PDMS as well.

All feces collections during the study period (72 hours) were carried out by ICU nurses and transferred to preweighed buckets. In the case of watery or loose stools, stool collectors (Flexi-Seal FMS (fecal management system); ConvaTec Woerden) were used; hard stools were collected directly from the hygiene pads. Minimal leakage was accepted, because we defined leakage as none, minimal (a minimal leakage like soiling the sheets), apparent (more than slight soiling of sheets to a definite amount of stools), and completely insufficient collection (for example, loss of sealing of the bag). The score was assessed by the preinstructed ICU nurse responsible for the fecal collections from the patients. Everything more than minimal fecal loss excluded the patient's fecal collection from the study. Feces were weighed (FWW in grams/day), homogenized, and immediately stored at $<4^{\circ} \mathrm{C}$ until analysis. To measure fecal macronutrient contents and to calculate the intestinal absorption capacity of the ICU patients, feces were analyzed for energy, fat, and nitrogen content. The fecal fat content $\left(\mathrm{F}_{\mathrm{Fat}}\right)$ was determined by the Van de Kamer method [33]. On a sample of wet stools, total nitrogen analysis was performed with the micro-Kjeldahl method to determine fecal nitrogen content $\left(\mathrm{F}_{\text {Nitrogen }}\right)$ by using previously described catalytic and digestive conditions [34]. Fecal protein content ( $\left.\mathrm{F}_{\text {Protein }}\right)$ was calculated by using a conversion factor, assuming that all of $\mathrm{F}_{\text {Nitrogen }}$ was derived from protein: $F_{\text {Protein }}(\mathrm{g} /$ day $)=\mathrm{F}_{\text {Nitrogen }}(\mathrm{g} /$

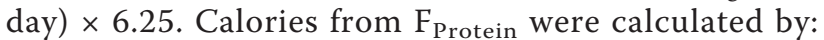
$\mathrm{F}_{\text {Protein }} \times 4.4 \mathrm{kcal} /$ day. Subsequently, a sample was taken and freeze dried to be processed by bomb calorimetry, a procedure that determines the heat of combustion of materials that are burned as fuels, and converts this into its energy value $[35,36]$. These calorimetric determinations represented daily fecal energy loss $\left(\mathrm{F}_{\text {Energy }}\right)$ in kcal/ day and were performed with the Gallenkamp Ballistic bomb calorimeter, type CBB-33, at University Groningen,
The Netherlands. Finally, fecal carbohydrate content $\left(\mathrm{F}_{\text {Carbohydrate }}\right)$ was calculated from the nonfat, nonprotein, and nonwater fraction of stools (that is, the fecal "rest", and was calculated with the following formula:

$$
\{\mathrm{EQ}\} \mathrm{F}_{\text {Carbohydrate }}(\mathrm{g} / \text { day })=\left(\mathrm{F}_{\text {Energy }}-\mathrm{F}_{\text {Fat }} \times 9.4-\mathrm{F}_{\text {Protein }} \times 4.4\right) / 4.10 \text {. }
$$

The intestinal absorption capacity (in percentage) of ingested energy from macronutrients was finally calculated as follows:

$$
\{\text { EQ }\}\left(\text { TEN }-F_{\text {Energy }} / \text { TEN }\right) \times 100 .
$$

Intestinal energy malabsorption was defined as an absorption capacity of $85 \%$ or less [31,37] (derived from intestinal energy-absorption data (90\%) in healthy controls; mean minus 1 SD). Specific intestinal malabsorption of fat, protein, and carbohydrate was a priori defined as an absorption capacity of $85 \%$ or less. Finally, the total energy balance was calculated as

$$
\{E Q\} \text { TEN - TEE - F Fnergy }
$$

\section{Statistical analysis}

Descriptive data are presented as means \pm SD or medians (with interquartile range) when appropriate. Diagnostic accuracy was depicted by using ROC, and the sensitivity (Se), specificity (Sp), and positive (PPV) and negative predicted values (NPVs) were calculated, as well as the Youden Index (Y, sensitivity + specificity 1 ), in which $Y=1$ corresponds to a perfect test, and $Y$ $=0$ has no diagnostic value [38]. The amount of feces with most optimal diagnostic-accuracy characteristics for malabsorption was used as a cut-off to allocate patients to one of the two groups ("normal stools" and "diarrhea"). Differences between groups were compared with the Student $t$ test. The Pearson $\chi^{2}$ test was used to explore relations between variables. The strength of the correlation was determined for continuous variables with the Spearman $r$. An acceptable level of statistical significance was established at $P<0.05$. All data were analyzed by using software package SPSS (Statistical Package for Social Sciences, Inc., Chicago, IL, USA, for Windows version 15.0).

\section{Results}

Table 1 shows the clinical characteristics of the 48 patients analyzed. As shown, "normal stools" patients and "diarrhea" patients were comparable for sex, age, weight, and height, as well as for energy and macronutrient intake and energy expenditure (Table 2). No difference was found in energy and protein supply of patients between the two groups $(29.1 \pm 9.2$ and $26.3 \pm$ $6.1 \mathrm{kcal} / \mathrm{kg} /$ day, and $1.2 \pm 0.3$ and $1.2 \pm 0.4$ g protein/ 
Table 1 ICU patients demographic data per group

\begin{tabular}{|c|c|c|c|}
\hline & $\begin{array}{l}<350 \mathrm{~g} / \text { day feces } \\
\text { (normal stools) }\end{array}$ & $\begin{array}{l}>350 \mathrm{~g} / \text { day feces } \\
\text { (diarrhea) }\end{array}$ & $P$ value \\
\hline \multicolumn{4}{|c|}{ Demographic data } \\
\hline$n$ & 38 & 10 & \\
\hline Gender, $0^{x} / Q$ & $22: 16$ & $6: 4$ & \\
\hline Age (year) & $63.1 \pm 15.9$ & $64.7 \pm 13.8$ & 0.773 \\
\hline Height $^{a}(\mathrm{~m})$ & $1.74 \pm 0.09$ & $1.70 \pm 0.07$ & 0.174 \\
\hline Weight $^{a}(\mathbf{k g})$ & $78.4 \pm 16.4$ & $76.1 \pm 17.3$ & 0.696 \\
\hline BMI $\left(\mathrm{kg} / \mathrm{m}^{2}\right)$ & $25.9 \pm 5.6$ & $26.1 \pm 4.3$ & 0.907 \\
\hline SOFA $^{b}$ & $5.6 \pm 2.8$ & $9.4 \pm 4.1$ & 0.001 \\
\hline APACHE-II ${ }^{b}$ & $22.8 \pm 7.3$ & $30.6 \pm 11.7$ & 0.023 \\
\hline \multirow[t]{2}{*}{ ICU admission } & 13 surgical patients & 5 surgical patients & \\
\hline & 25 medical patients $^{c}$ & 5 medical patients & \\
\hline
\end{tabular}

${ }^{\mathrm{a}}$ Height and weight are estimated values. ${ }^{\mathrm{b}} \mathrm{At}$ day of admission into ICU. ${ }^{\mathrm{C}}$ Medical diagnosis included neurologic injury, respiratory failure, sepsis, and others). APACHE-II, Acute Physiology and Chronic Health Evaluation II; BMI, body mass index; SOFA, Sequential Organ Failure Assessment.

$\mathrm{kg} /$ day for patients with normal stools and diarrhea, respectively). Use of laxatives, antibiotics, vasoactive medication, and diuretics was not different between both groups as well. Patients did not receive renal replacement therapy as per protocol. APACHE-II and SOFA scores were higher in the group of diarrhea $(>350 \mathrm{~g} /$ day) than in the group with normal stools $(<350 \mathrm{~g} /$ day $)$, indicative of a more severely ill group.

\section{Fecal weight as a diagnostic tool for energy malabsorption}

Figure 1 shows the ROC curves for diagnostic accuracy of different cut-off points of fecal weight (ranging from 230 to $400 \mathrm{~g} /$ day) as a biomarker for energy malabsorption. Based on these ROC curves, the diagnostic accuracy (Table 3) was optimal with a cut-off daily fecal

Table 2 ICU patient energy expenditure and nutrient intake per group

\begin{tabular}{llll}
\hline & $\begin{array}{l}<\mathbf{3 5 0} \mathbf{g} / \text { day } \\
\text { feces } \\
\text { (normal stools) }\end{array}$ & $\begin{array}{l}>350 \text { g/day } \\
\text { feces } \\
\text { (diarrhea) }\end{array}$ & $\begin{array}{l}P \\
\text { value }\end{array}$ \\
\hline $\begin{array}{l}\text { Energy expenditure } \\
\text { TEE (kcal/day) }\end{array}$ & $2,068 \pm 380$ & $2,044 \pm 361$ & 0.872 \\
$\begin{array}{l}\text { Nutrient intake } \\
\text { Energy (gross) }\end{array}$ & & & \\
(kcal/day) & $2,218 \pm 626$ & $1,941 \pm 335$ & 0.186 \\
(kcal/kg/day) & $29.1 \pm 9.2$ & $26.3 \pm 6.1$ & 0.370 \\
$\begin{array}{l}\text { Fat (g/day) } \\
\text { Protein (g/day) }\end{array}$ & $77.7 \pm 22.4$ & $72.0 \pm 16.6$ & 0.457 \\
(g/kg/day) & $1.2 \pm 0.3$ & $85.5 \pm 17.9$ & 0.372 \\
$\begin{array}{l}\text { Carbohydrate (g/ } \\
\text { day) }\end{array}$ & $236.9 \pm 62.8$ & $1.2 \pm 0.4$ & 0.729 \\
\hline
\end{tabular}

${ }^{\mathrm{C}} \mathrm{TEE}$, total energy expenditure; $n=29$. ${ }^{\mathrm{d}}$ Energy intake is calculated as gross energy intake, not as energy intake available for metabolization (as is usual with regular calculation of nutrient intake) weight of $350 \mathrm{~g}$, displaying the largest area under the curve (0.875) with a Youden Index (0.76). Additionally, Se was $80 \%$; Sp, 96\%; the PPV, $80 \%$; and the NPV, $96 \%$. The high specificity and high NPV (both 96\%) indicated that "no diarrhea" was clinically equivalent to "no malabsorption". If a fecal production of $250 \mathrm{~g} /$ day was used as the cut-off, test sensitivity was $90 \%$; thus a fecal weight below this number reasonably excluded malabsorption. However, PPV for actual malabsorption by using this fecal weight as the reference value was only $53 \%$, which may lead to overdiagnosis.

FWW (g/day) and energy-absorption capacity were inversely correlated (Spearman $r=-0.69 ; P<0.001$ ) (Figure 2). More than $350 \mathrm{~g} /$ day feces was statistically significantly associated with an energy-absorption coefficient of less than $85 \%\left(P<0.001 ; \chi^{2}\right.$ test $)$.

\section{Fecal composition, absorption capacity, and energy balance}

Ten $(21 \%)$ of $48(n=10)$ of the included patients were classified as having diarrhea (> $350 \mathrm{~g} /$ day feces and were therefore classified to be at increased risk for energy malabsorption. Fecal composition and the intestinalabsorption capacity for energy and macronutrients for both groups are shown in Table 4. Patients with normal stools had a significantly lower total daily fecal energy loss $(\mathrm{kcal} / \mathrm{d})$ compared with patients with diarrhea $(P<0.001)$; however, fecal energetic content per gram of feces $(\mathrm{kcal} / \mathrm{g}$ wet feces) was not significantly different $(P=0.135)$ between groups. Of $48 \mathrm{ICU}$ patients, nine were ultimately diagnosed with energy malabsorption $(<85 \%)$, of whom only one patient had a fecal production of $<350 \mathrm{~g} /$ day.

As might be expected, not only $\mathrm{F}_{\mathrm{Fat}}$, but also $\mathrm{F}_{\text {Protein }}$ and $F_{\text {Carbohydrate }}$ losses were significantly higher in the patients with diarrhea than in ICU patients with normal stools $(P<0.001)$. As a consequence, energy-absorption capacity was significantly lower in these patients $(P<$ 0.001), paralleling fat, protein, and carbohydrate absorption capacity. Protein and carbohydrate absorption capacity were also both negatively correlated with total FWW (Spearman $r=-0.85 ; P<0.001$; and $r=-0.69$; $P$ $<0.001$, respectively). The correlation between fatabsorption capacity and FWW was less strong (Spear$\operatorname{man} r=-0.27 ; P<0.001$.

No differences were found between men and women for fecal composition or for intestinal-absorption capacity.

Patients with $>350 \mathrm{~g}$ feces/day had a significantly more negative energy balance compared with patients with $<350 \mathrm{~g} /$ day feces (loss of $627 \mathrm{kcal} /$ day versus neutral balance; $P=0.012$ ).

\section{Discussion}

The current study explored fecal energy and macronutrient composition and fecal weight to see whether this 


\section{ROC Curve}

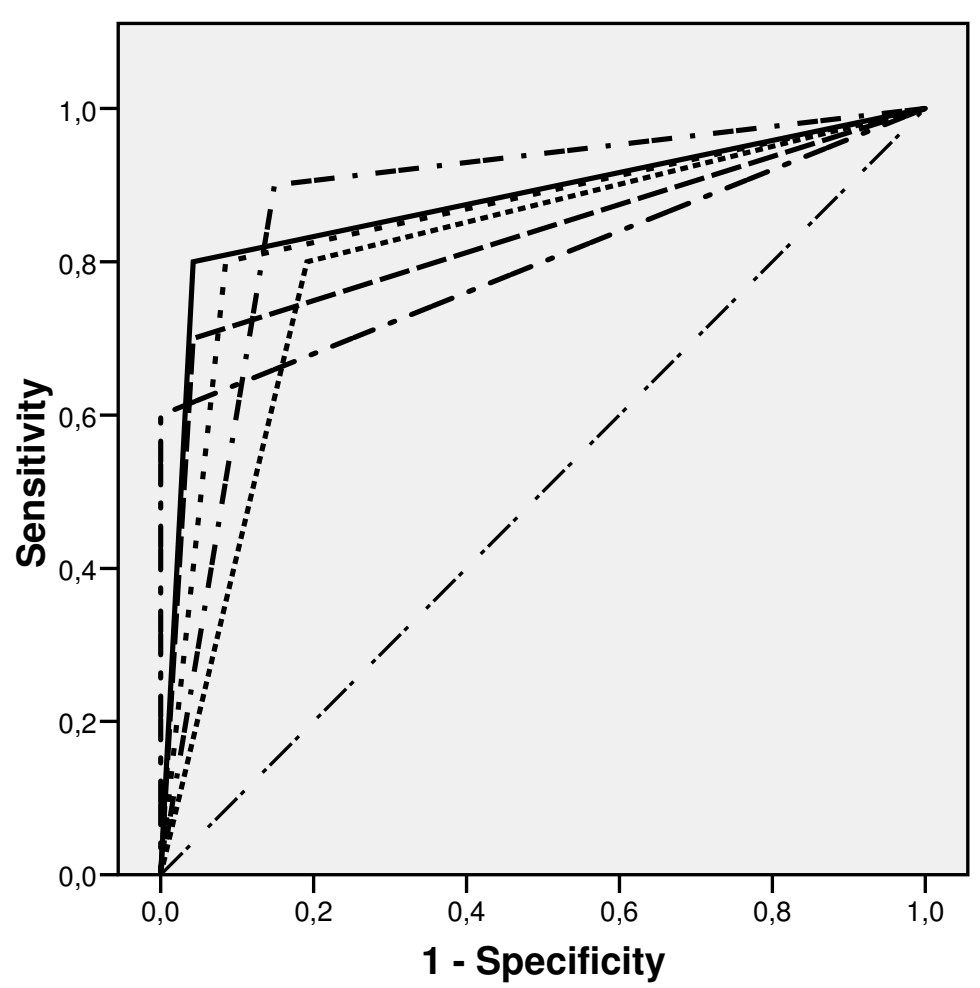

Source of the Curve

...-. Faeces 230 gram

- - Faeces 250 gram

- - Faeces 300 gram

- Faeces 350 gram

- Faeces 375 gram

- Faeces 400 gram

- Reference Line

Figure 1 ROC curves for diagnostic accuracy of fecal weight (grams/day) to diagnose malabsorption in ICU patients. The receive operator characteristic curves (ROCs) for diagnostic accuracy of different cut-off points of fecal wet weight (FWW) (ranging from 230 to $400 \mathrm{~g} /$ day) as a biomarker for malabsorption. Based on these ROC curves, the diagnostic accuracy of daily fecal weight of $350 \mathrm{~g}$ was most optimal, showing sensitivity of $80 \%$; specificity, $96 \%$; positive predictive value (PPV), 80\%; and a negative predictive value (NPV) of $96 \%$. Additionally, the accompanying area under the curve (AUC) and the Youden Index indicated that $350 \mathrm{~g}$ FWW was the best cut-off value for energy malabsorption.

could be used as a diagnostic tool for intestinal absorption capacity in a cohort of stable ICU patients without a priori intestinal disease or intestinal failure. In this extended series, we demonstrated fecal weight to be a practical and reliable biomarker for malabsorption in ICU patients; a clinical finding being present in one of five stable ICU patients [27]. A daily fecal weight of more than 350 g provided optimal diagnostic accuracy and may therefore be recommended as a quick and easy screening tool for diagnosing malabsorption in ICU patients.

Nutritional guidelines for ICU patients focus mainly on adequate energy and protein provision. Remarkably, the absorptive capacity of the bowel is not taken into account in any of these guidelines, neglecting the fact that these patients commonly have gastrointestinal dysfunction caused mainly by failing intestinal motility [6]. Malabsorption (here defined as energy intestinal

Table 3 The diagnostic accuracy of fecal weight in diagnosing malabsorption in ICU patients

\begin{tabular}{lllllll}
\hline $\begin{array}{l}\text { Cut-off point (g/day } \\
\text { feces) }\end{array}$ & $\begin{array}{l}\text { Sensitivity } \\
(\%)\end{array}$ & $\begin{array}{l}\text { Specificity } \\
(\%)\end{array}$ & $\begin{array}{l}\text { Positive predictive value } \\
(\%)\end{array}$ & $\begin{array}{l}\text { Negative predicted value } \\
\text { (\%) }\end{array}$ & $\begin{array}{l}\text { Youden } \\
\text { index }\end{array}$ & $\begin{array}{l}\text { ROC } \\
\text { AUC }\end{array}$ \\
\hline $\mathbf{2 3 0}$ & 80 & 81 & 47 & 97 & 0.61 & 0.804 \\
$\mathbf{2 5 0}$ & 90 & 85 & 53 & 98 & 0.75 & 0.876 \\
$\mathbf{3 0 0}$ & 80 & 92 & 67 & 96 & 0.72 & 0.875 \\
350 & 80 & 96 & 80 & 96 & 0.76 & 0.879 \\
$\mathbf{3 7 5}$ & 70 & 96 & 86 & 94 & 0.66 & 0.829 \\
$\mathbf{4 0 0}$ & 60 & 100 & 100 & 92 & 0.60 & 0.800 \\
\hline
\end{tabular}

$A \cup C$, area under the curve; $\mathrm{ROC}$, receiver operator curve. 


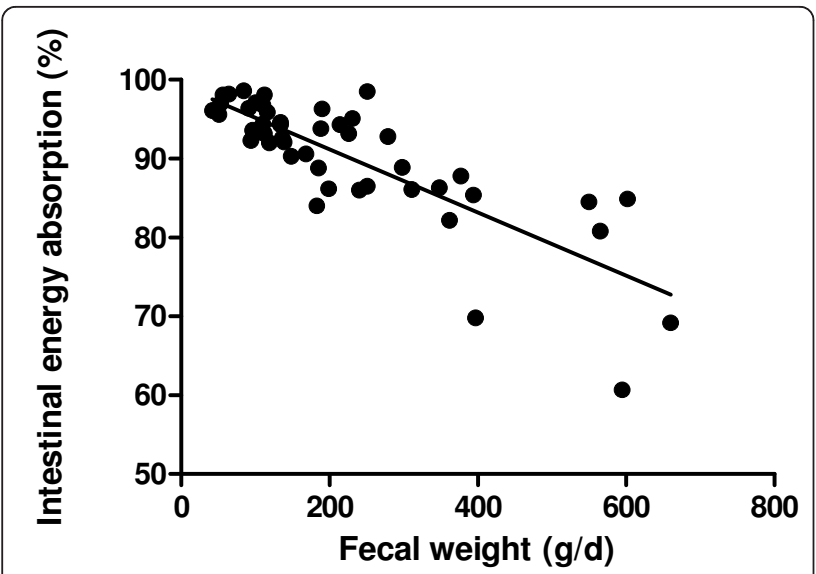

Figure 2 Relation between fecal wet weight (grams/day) and energy absorption capacity (\%). The relation between fecal wet weight (FWW) (grams/day) and intestinal energy absorption capacity in 47 stable ICU patients, is inversely correlated (Spearman's $r=$ $-0.69 ; P<0.001)$. More than $350 \mathrm{~g} /$ day feces was statistically significantly associated with an energy-absorption coefficient of less than $85 \%\left(P<0.001 ; \chi^{2}\right.$ test). One outlier is left out of the analysis and picture $(3,458 \mathrm{~g} ; 60 \%)$.

absorption capacity of $<85 \%$, and thus a pragmatic definition of the intestinal function) was frequently observed in this series (one of five stable ICU patients), which even may be an underestimate of the general ICU population, when considering patients in a more-unstable condition, such as sepsis, MODS, and severe trauma. In the patient group with diarrhea, mean daily FWW was approximately $800 \mathrm{~g} /$ day, with a mean energetic content of $445 \mathrm{kcal} /$ day, resulting in a mean energetic absorption capacity of $77 \%$, whereas energy and protein absorption in a healthy population is (well) around 90\% (data not shown). Malabsorption is an important factor to be considered when aiming to achieve a neutral or preferably positive energy balance in this specific group of ICU patients, as we observed an average negative energy balance of more than $600 \mathrm{kcal} /$ day in the group of ICU patients at risk for malabsorption.

In addition, we demonstrated that in ICU patients with diarrhea (> $350 \mathrm{~g} /$ day feces), the observed decreased total intestinal absorption capacity applied for all macronutrients. Daily FWW was inversely related to intestinal malabsorption, constituting a simple biomarker of functional intestinal failure. Conversely, others have shown that postcardiac event ICU patients, without a priori intestinal dysfunction similar to our population, had disturbed intestinal motility but a normal intestinal absorption. Apart from a different study method, these patients seemed less severely ill than ours, and the intestinal motility disorders recovered apparently swiftly (only delayed intestinal absorption) [39].

Interestingly, we demonstrated that patients with diarrhea display remarkably higher fecal protein losses compared with patients with normal stools (16.2 g/day versus $5.6 \mathrm{~g} /$ day), contributing to the already existing catabolic state. The estimated amount of protein available for the body, calculated as the difference between protein intake and fecal protein loss, decreased below $1.0 \mathrm{~g}$ protein $/ \mathrm{kg} /$ day, which is considerably below the recommended optimal protein needs of 1.2 to $1.5 \mathrm{~g}$ protein $/ \mathrm{kg} /$ day [18-20]. Patients with diarrhea (> $350 \mathrm{~g} /$ day)

Table 4 Fecal composition and energy, fat, protein, and carbohydrate absorption capacity for ICU patients with normal stools and with diarrhea

\begin{tabular}{|c|c|c|c|}
\hline & $\begin{array}{l}<350 \mathrm{~g} / \text { day feces } \\
n=38 \\
\text { (normal stools) }\end{array}$ & $\begin{array}{l}>350 \mathrm{~g} / \text { day feces } \\
n=10 \\
\text { (diarrhea) }\end{array}$ & $P$ value \\
\hline \multicolumn{4}{|l|}{ Fecal composition } \\
\hline FWW (g/day) & $157 \pm 79$ & $796 \pm 942$ & $<0.001$ \\
\hline Percentage of dry weight (\%) & $17.6 \pm 5.8$ & $13.5 \pm 4.8$ & 0.047 \\
\hline $\mathrm{F}_{\text {Energy }}(\mathrm{kcal} /$ day) & $146.4 \pm 86.7$ & $445.5 \pm 201.3$ & $<0.001$ \\
\hline Energy wet feces (kcal/g) & $0.97 \pm 0.36$ & $0.78 \pm 0.37$ & 0.135 \\
\hline Energy dry feces (kcal/g) & $5.49 \pm 0.69$ & $5.59 \pm 1.09$ & 0.720 \\
\hline$F_{\text {Fat }}(g /$ day $)$ & $2.4 \pm 2.6$ & $11.4 \pm 14.3$ & $<0.001$ \\
\hline $\mathrm{F}_{\text {Nitrogen }}(\mathrm{g} /$ day $)$ & $0.9 \pm 0.5^{\mathrm{a}}$ & $2.6 \pm 1.1^{b}$ & $<0.001$ \\
\hline $\mathrm{F}_{\text {Protein }}(\mathrm{g} /$ day $)$ & $5.6 \pm 3.1^{a}$ & $16.2 \pm 7.1^{b}$ & $<0.001$ \\
\hline$F_{\text {Carbohydrate }}(g /$ day) & $24.1 \pm 17.7^{\mathrm{a}}$ & $52.1 \pm 18.9^{b}$ & 0.003 \\
\hline \multicolumn{4}{|l|}{ Absorption capacity } \\
\hline Energy absorption (\%) & $93.1 \pm 4.1$ & $76.5 \pm 10.6$ & $<0.001$ \\
\hline Fat absorption (\%) & $96.8 \pm 3.3$ & $84.7 \pm 17.2$ & $<0.001$ \\
\hline Protein absorption (\%) & $93.6 \pm 3.8^{\mathrm{a}}$ & $82.5 \pm 7.2^{b}$ & $<0.001$ \\
\hline Carbohydrate absorption (\%) & $89.6 \pm 6.7^{\mathrm{a}}$ & $74.5 \pm 12.9^{b}$ & $<0.001$ \\
\hline
\end{tabular}

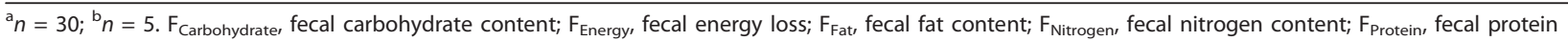
content; FWW, fecal wet weight. 
are therefore at higher risk for both a negative energy and a negative protein balance, of which the latter is related to increased risk for infections and mortality $[1,2]$.

The diarrhea frequently observed in ICU may be ascribed to several causes, including the use of drugs or laxatives. Apart from antibiotic use, such as in selective decontamination of the bowel, which is commonly carried out at our IC unit, no medication could be related in any way to the reported findings. Therefore, we suggest that the observed intestinal malabsorption truly reflects a failing organ. Whether this is caused by maldigestion, hypermotility, disbalances of gastrointestinal transport, or other causes cannot be stated with certainty, but is likely mainly to be associated with organ dysfunction of the gastrointestinal tract.

It may be hypothesized that increase of enteral feeding supplies (energy and protein) may have beneficial effects to counteract catabolism in case of voluminous stools in an ICU patient. Whether this should be a form of enteral hyperalimentation using polymeric or semi-elemental formulas in an ICU setting remains to be demonstrated. Finally, one might focus on the benefit versus risks of supplemental parenteral nutrition in case of (unexpected) functional intestinal failure in ICU patients. However, supplying TPN in current clinical practice appears to be reserved for patients with straightforward gastrointestinal failure [40], whereas, interestingly it was recently demonstrated by Thibault et al [41] that supplemental parenteral nutrition might prevent a negative energy balance in ICU patients after cardiogenic shock. The timing of starting TPN in the ICU group is under discussion and has recently been studied in the EPaNIC trial; late initiation might be preferable [42].

Several flaws exist in the current pilot study. The number of patients is relatively limited, and measurements were chosen for feasibility in clinical practice to identify a practically applicable biomarker. This limited the precision of measurements of energy and protein losses. On the contrary, the study population had to be fed enterally, which forms the majority (about 90\%) of the population of the usual ICU patients. Our studies patients were stable but seriously ill, and a priori, no malabsorption was expected. They seemed to be a representative group of ICU patients (for sex, age, height, weight, BMI, SOFA scores, APACHE-II scores, and medical diagnosis), which is a strength of the study. TPN is reserved for a specific small group of ICU patients. The observed findings seem to apply to moresevere patients as well, as long as they are fed enterally.

\section{Conclusions}

In conclusion, we propose to quantify daily FWW in the ICU as a clinically feasible biomarker for clinically significant malabsorption in ICU patients, in particular, in case of diarrhea. Absorption of both energy and all macronutrients is significantly less in patients if fecal output exceeds 350 g/day. Further studies are warranted to confirm the obtained data in this pilot and to establish whether increasing enteral supplies is of clinical benefit to counteract catabolism in these patients. Our findings may improve recognition of potential malabsorption, especially in patients with severe illness and voluminous stools.

\section{Key messages}

- Malabsorption is a clinical finding present in one of five "stable" ICU patients.

- Quantifying daily fecal weight is a clinically feasible biomarker for clinically significant malabsorption in ICU patients.

- Intestinal absorption of energy and macronutrients is significantly lower in ICU patients if the fecal output exceeds $350 \mathrm{~g} /$ day.

- ICU patients with a fecal output > $350 \mathrm{~g} /$ day are at a high risk for a negative energy and protein balance, with subsequent increased risk for infections and mortality.

- The amount of or the way by which the energy and proteins must be administered must be adapted in ICU patients having voluminous stools.

\section{Abbreviations}

AEE: activity energy expenditure; APACHE II score: Acute Physiology and Chronic Health Evaluation II score; BMI: body mass index; CIIP: chronic intermittent intestinal pseudo obstruction; CRRT: continuous renal replacement therapies; EPaNIC trial: impact of early parenteral nutrition completing enteral nutrition in adult critically ill patients; $F_{\text {Carbohydrate: the }}$ daily fecal carbohydrate content in grams per day; $F_{\text {Energy: }}$ the daily fecal energy loss in kcal per day; $F_{\text {Fat: }}$ the daily fecal fat content in grams per day;

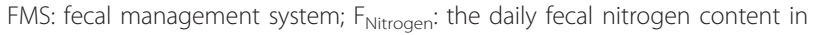
grams per day; $F_{\text {Protein: }}$ the daily fecal protein content in grams per day; FWW: fecal wet weight in grams per day; g/day: grams per day; g/kg: grams per kilogram; GIF: gastrointestinal failure score; IBD: inflammatory bowel disease; ICU: intensive care unit; Kcal/day: kilocalories per day; MOF: multiple organ failure; NPV: negative predictive value; PDMS: patient datamanagement system; PEEP: positive end-expiratory pressure; PEM: proteinenergy malnutrition; PPV: positive predictive value; REE: resting energy expenditure; ROC: receiver operator curve; SD: standard deviation; Se: sensitivity; SOFA score: Sequential Organ Failure Assessment score; Sp: specificity; TEE: total energy expenditure; TEN: total actual nutritional intake of energy; TPN: total parenteral nutrition.

\section{Acknowledgements}

The authors thank the laboratory of Groningen University and the employees of the central laboratory of the VU University Medical Center for preparing and analyzing the fecal samples. The research nurses (Erna Alberts and Ingrid van de Hul) and students from school for Nutrition and Dietetics and from VU University (Health Sciences) contributed substantially in collecting data, handling materials, and analysis. Last but not least, we thank Rob Strack van Schijndel, intensivist in the VU University Medical Center until 2009, who participated in the design of the study and who was very inspiring and enthusiastic. Unfortunately, he died during this research process.

\section{Author details}

${ }^{1}$ Department of Nutrition and Dietetics, VU University Medical Center, De Boelelaan 1117, 1081 HV Amsterdam, The Netherlands. ${ }^{2}$ Department of 
Gastroenterology and Hepatology, Red Cross Hospital, Vondellaan 13, 1942 LE Beverwijk, The Netherlands. ${ }^{3}$ Department of Intensive Care, VU University Medical Center, De Boelelaan 1117, 1081 HV Amsterdam, The Netherlands. ${ }^{4}$ Department of Gastroenterology, Small Bowel Unit, VU University Medical Center, De Boelelaan 1117, 1081 HV Amsterdam, The Netherlands.

\section{Authors' contributions}

MK included the patients, supervised the collection of specimens, and performed the metabolic measurements. JP and AAB participated in the design of the study and the drafting of the manuscript. PW participated in the design of the study and performed the statistical analysis. NW included the patients, supervised the collection of specimens, performed the metabolic measurements, performed the statistical analyses, and participated in the design of the study and the drafting of the manuscript. AB included the patients, supervised the collection of specimens, performed the metabolic measurements, and participated in the design of the study, and in drafting the manuscript. All authors read and approved the final manuscript for publication.

\section{Competing interests}

The author(s) declare that they have no competing interests. The authors have no affiliations or financial involvement with any organization or entity with a financial interest in or financial conflict with the subject matter or materials discussed in the article.

Received: 17 May 2011 Revised: 21 September 2011

Accepted: 9 November 2011 Published: 9 November 2011

\section{References}

1. Villet S, Chiolero RL, Bollmann MD, Revelly JP, Cayeux RNMC, Delarue J, Berger MM: Negative impact of hypocaloric feeding and energy balance on clinical outcome in ICU patients. Clin Nutr 2005, 24:502-509.

2. Dempsey DT, Mullen $\mathrm{J}$, Buzby GP: The link between nutritional status and clinical outcome: can nutritional intervention modify it? Am J Clin Nutr 1988, 47:352-356.

3. Dvir D, Cohen J, Singer P: Computerized energy balance and complications in critically ill patients: an observational study. Clin Nutr 2006, 25:37-44.

4. Bartlett RH, Dechert RE, Mault JR, Ferguson SK, Kaiser AM, Erlandson EE: Measurement of metabolism in multiple organ failure. Surgery 1982, 92:771-779.

5. Alberda C, Gramlich L, Jones N, Jeejeebhoy K, Day AG, Dhaliwal R, Heyland DK: The relationship between nutritional intake and clinical outcomes in critically ill patients: results of an international multicenter observational study. Intensive Care Med 2009, 35:1728-1737.

6. Reintam A, Parm P, Kitus R, Starkopf J, Kern H: Gastrointestinal failure score in critically ill patients: a prospective observational study. Crit Care 2008, 12:R90.

7. Giner M, Laviano A, Meguid MM, Gleason JR: In 1995 a correlation between malnutrition and poor outcome in critically ill patients still exists. Nutrition 1996, 12:23-29.

8. Strack van Schijndel RJ, Weijs PJM, Koopmans RH, Sauerwein HP, Beishuizen A, Girbes AR: Optimal nutrition during the period of mechanical ventilation decreases mortality in critically ill, long-term acute female patients: a prospective observational cohort study. Crit Care 2009, 13:R132.

9. Doig GS, Heighes PT, Simpson F, Sweetman EA, Davies AR: Early enteral nutrition, provided within $24 \mathrm{~h}$ of injury or intensive care unit admission, significantly reduces mortality in critically ill patients: a metaanalysis of randomised controlled trials. Intensive Care Med 2009, 35:2018-2027.

10. Heyland DK, Stephens KE, Day AG, McClave SA: The success of enteral nutrition and ICU-acquired infections: a multicenter observational study. Clin Nutr 2011, 30:148-155.

11. Weijs PJM, Stapel SN, Groot de SDW, Driessen RH, Jond de E, Girbes ARJ, Beishuizen A: Optimal protein and energy nutrition decreases mortality in mechanically ventilated critically ill patients: a prospective observational cohort study. JPEN 2011.

12. Berger MM, Revelly JP, Cayeux MC, Chiolero RL: Enteral nutrition in critically ill patients with severe hemodynamic failure after cardiopulmonary bypass. Clin Nutr 2005, 24:124-132.
13. Jolliet P, Pichard C, Biolo G, Chioléro R, Grimble G, Leverve X, Nitenberg G, Novak I, Planas M, Preiser JC, Roth E, Schols AM, Wernerman J: Enteral nutrition in intensive care patients: a practical approach. Intensive Care Med 1998, 24:848-859.

14. Elia M, Stubbs RJ, Henry CJ: Differences in fat, carbohydrate, and protein metabolism between lean and obese subjects undergoing total starvation. Obesity Res 1999, 7:597-604.

15. Dulloo AG, Jacquet J: The control of partitioning between protein and fat during human starvation: its internal determinants and biological significance. Br J Nutr 1999, 82:339-356.

16. Roza AM, Shizgal HM: The Harris Benedict equation reevaluated: resting energy requirements and the body cell mass. Am J Clin Nutr 1984, 40:168-182.

17. Lanschot van JJ, Feenstra BW, Vermeij CG, Bruining HA: Calculation versus measurement of total energy expenditure. Crit Care Med 1986, 14:981-985.

18. Sauerwein HP, Strack van Schijndel RJ: Perspective: how to evaluate studies on peri-operative nutrition? Considerations about the definition of optimal nutrition for patients and its key role in the comparison of the results of studies on nutritional intervention. Clin Nutr 2007, 26:154-158.

19. Ishibashi N, Plank LD, Sando K, Hill GL: Optimal protein requirements during the first 2 weeks after the onset of critical illness. Crit Care Med 1998, 26:1529-1535.

20. Shaw JH, Wildbore M, Wolfe RR: Whole body protein kinetics in severely septic patients: the response to glucose infusion and total parenteral nutrition. Ann Surg 1987, 205:288-294.

21. Mutlu GM, Mutlu EA, Factor P: GI complications in patients receiving mechanical ventilation. Chest 2001, 119:1222-1241.

22. Mentec $\mathrm{H}$, Dupont $\mathrm{H}$, Bocchetti M, Cani P, Ponche F, Bleichner G: Upper digestive intolerance during enteral nutrition in critically ill patients: frequency, risk factors, and complications. Crit Care Med 2001, 29:1955-1961.

23. Reintam A, Parm P, Redlich U, Tooding LM, Starkopf, Kohler F, Spies C, Kern $\mathrm{H}$ : Gastrointestinal failure in intensive care: a retrospective clinical study in three different intensive care units in Germany and Estonia. BMC Gastroenterol 2006, 6:19.

24. Montejo JC, Grau T, Acosta J, Planas M, García-De-Lorenzo A, Mesejo A, Cervera M, Sánchez-Alvarez C, Núñez-Ruiz R, López-Martínez J: Multicenter, prospective, randomized, single-blind study comparing the efficacy and gastrointestinal complications of early jejunal feeding with early gastric feeding in critically ill patients. Crit Care Med 2002, 30:796-800.

25. Piton G, Manzon C, Cypriani B, Carbonnel F, Capellier G: Acute intestinal failure in critically ill patients: is plasma citrulline the right marker? Intensive Care Med 2011, 6:911-917.

26. Winawer SJ, Broitman SA, Wolochow DA, Osborne MP, Zamcheck N: Successful management of massive small-bowel resection based on assessment of absorption defects and nutritional needs. N Engl J Med 1966, 274:72-78.

27. Strack van Schijndel RJ, Wierdsma NJ, van Heijningen EM, Weijs PJM, de Groot SD, Girbes AR: Fecal energy losses in enterally fed intensive care patients: an explorative study using bomb calorimetry. Clin Nutr 2006, 25:758-764.

28. Brandi LS, Bertolini R, Calafa M: Indirect calorimetry in critically ill patients: clinical applications and practical advice. Nutrition 1997, 13:349-358.

29. Swinamer DL, Phang PT, Jones RL, Grace M, King EG: Twenty-four hour energy expenditure in critically ill patients. Crit Care Med 1987, 15:637-643.

30. Merill AL, Watt BK: Energy value of foods, basis and derivation. Agriculture Handbook United States Department of Agriculture, Washington, DC; 1995.

31. Southgate DA, Durnin JV: Calorie conversion factors: an experimental reassessment of the factors used in the calculation of the energy value of human diets. Br J Nutr 1970, 24:517-535.

32. Strack van Schijndel RJM, Weijs PJM, Sauerwein HP, Groot de SDW, Beishuizen A, Girbes ARJ: An algorithm for balanced protein/energy provision in critically ill mechanically ventilated patients. e-SPEN 2007, 2:69-74.

33. Van de Kamer $\mathrm{JH}$, Ten Bokkel Huinink H, Weyers HA: Rapid method for determination of fat in feces. J Biol Chem 1949, 177:347-355. 
34. Rudman D, Millikan WJ, Richardson TJ, Bixler TJ II, Stackhouse WJ,

McGarity WC: Elemental balances during intravenous hyperalimentation of underweight adult subjects. J Clin Invest 1975, 55:94-104.

35. Lovelady HG, Stork EJ: An improved method for preparation of feces for bomb calorimetry. Clin Chem 1970, 16:253-254.

36. Miller DS, Payne PR: A ballistic bomb calorimeter. Br J Nutr 1959, 13:501-508.

37. Heymsfield SB, Smith J, Kasriel S, Barlow J, Lynn MJ, Nixon D, Lawson DH: Energy malabsorption: measurement and nutritional consequences. Am J Clin Nutr 1981, 34:1954-1960.

38. Youden WJ: Index for rating diagnostic tests. Nat Rev Cancer 1950, 3:32-35, (abstr).

39. Berger MM, Berger-Gryllaki M, Wiesel PH, Revelly JP, Jurni M, Cayeux C, Tappy L, Chiolero R: Intestinal absorption in patients after cardiac surgery. Crit Care Med 2000, 28:2217-2223.

40. Griffiths RD, Bongers T: Nutrition support for patients in the intensive care unit. Postgrad Med J 2005, 81:629-636.

41. Thibault R, Pichard C, Wernerman J, Bendjelid K: Cardiogenic shock and nutrition: safe? Intensive Care Med 2011, 37:35-45.

42. Casaer MP, Mesotten D, Hermans G, Wouters PJ, Schetz M, Meyfroidt G, Van Cromphaut S, Ingels C, Meersseman P, Muller J, Vlasselaers D, Debaveye $Y$, Desmet L, Dubois J, Van Assche A, Vanderheyden S, Wilmer A, Van den Berghe G: Early versus late parenteral nutrition in critically ill adults. $N$ Engl J Med 2011, 365:506-517.

\section{doi:10.1186/cc10530}

Cite this article as: Wierdsma et al: Malabsorption and nutritional balance in the ICU: fecal weight as a biomarker: a prospective observational pilot study. Critical Care 2011 15:R264.

\section{Submit your next manuscript to BioMed Central and take full advantage of:}

- Convenient online submission

- Thorough peer review

- No space constraints or color figure charges

- Immediate publication on acceptance

- Inclusion in PubMed, CAS, Scopus and Google Scholar

- Research which is freely available for redistribution

Submit your manuscript at www.biomedcentral.com/submit
Biomed Central 